\title{
Renovation of MCK to improve community health in pangambatan village, brand district, Karo Sumut regency
}

\author{
Firman Eddy $^{1 *}$, Hilma Tamiami Fachrudin ${ }^{1}$, Imam Faisal Pane ${ }^{1}$, Hesti Fibriasari ${ }^{2}$ \\ ${ }^{1}$ Department of Architecture, Faculty of Engineering, Universitas Sumatera Utara \\ ${ }^{2}$ Department of French Language, Faculty of Language and Art, Universitas Negeri Medan \\ *Email: rechvidimaz@yahoo.com
}

\begin{abstract}
Community service activities are one of the TRI DHARMA university's obligations. On this occasion, it was reported that community service activities needed improvement in the health sector. The location of this activity is in Pangambatan Village, Kecamatan Merek, Kabupaten Karo, Sumatera Utara and this activity is planned to begin in April until September 2019. The problem in the field is to increase the flow of tourists to Kecamatan Merek to make the need for adequate toilet facilities (MCK). Besides that, it was also found that the community's need for clean water and toilets were used daily by the community. The solution offered is to renovate the MCK facilities for the daily needs of the community and in addition to the toilet facilities for tourists who visit to the village. It is hoped that through this activity the problems in the local community can be overcome.
\end{abstract}

\section{Keyword: Desa Pangambatan, Toilet Facilities, Public Health}

\begin{abstract}
Abstrak
Kegiatan pengabdian masyarakat adalah salah satu kewajiban universitas TRI DHARMA. Pada kesempatan ini, dilaporkan bahwa kegiatan pelayanan masyarakat membutuhkan peningkatan di sektor kesehatan. Lokasi kegiatan ini berada di Desa Pangambat, Kabupaten Brand, Kabupaten Karo, Sumatera Utara dan kegiatan ini direncanakan akan dimulai pada bulan April hingga September 2019. Masalahnya di lapangan adalah meningkatkan arus wisatawan ke Kabupaten Merek untuk membuat kebutuhan. untuk fasilitas toilet yang memadai (MCK). Selain itu, ditemukan juga bahwa kebutuhan masyarakat akan air bersih dan toilet digunakan setiap hari oleh masyarakat. Solusi yang ditawarkan adalah merenovasi fasilitas MCK untuk kebutuhan seharihari masyarakat dan di samping fasilitas toilet untuk wisatawan yang berkunjung ke desa. Diharapkan melalui kegiatan ini masalah di masyarakat setempat dapat diatasi.
\end{abstract}

Kata Kunci: Desa Pengambatan, fasilitas toilet, kesehatan masyarakat

\section{PENDAHULUAN}

Pemerintah dalam salah satu program kerjanya adalah meningkatkan industri pariwisata. Industri ini dianggap signifikan dalam memperkenalkan potensi daerah terutama budaya setempat. Keanekaragaman bentuk pariwisata saat ini telah dilakukan untuk menarik minat para wisatawan berkunjung ke suatu tempat. Potensi yang dimiliki suatu tempat berkaitan dengan keunikan budaya dan adat istiadat yang dimiliki oleh tempat tersebut (Tuan, 1977; Norberg-Schulz, 1980; Ginting dan Rahman, 2016). Untuk itu perlunya meningkatkan pariwisata dengan cara meningkatkan sarana dan prasana untuk keberlanjutannya.

Desa pengambatan merupakan desa yang memiliki luas $1000 \mathrm{~km} 2$ dan merupakan desa nomor 2 terluas dari 19 Desa yang ada di Kecamatan Merek. 


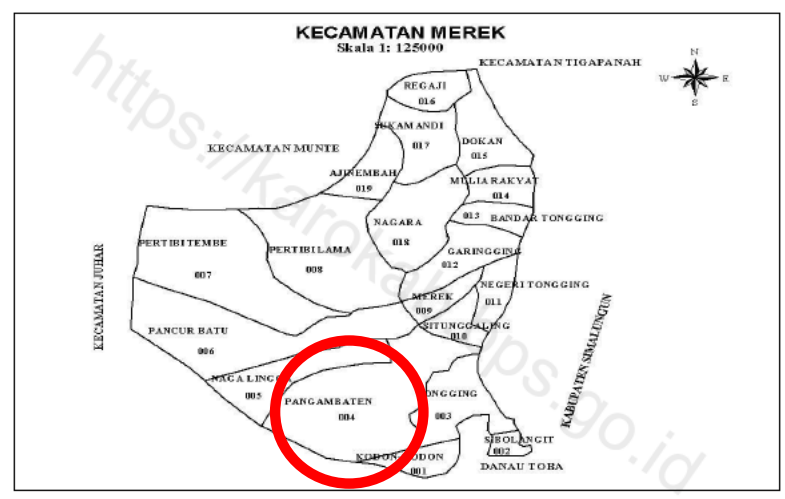

Gambar 1.Desa Pangambatan Kecamatan Merek Kabupaten Karo (Sumber: BPS 2017)

Posisi dari Desa tersebut diapait oleh Desa Nagalingga, Desa Kodon-Kodon dan Desa Tongging. Memiliki 5 (lima) Dusun dan memiliki tinggi 1506 dpl (Gambar 1). Selain faktor wisata, faktor meningkatkan kesehatan masyarakat menjadi perhatian pada kegiatan pengabdian ini. Masyarakat membutuhkan air bersih dan sarana MCK untuk kehidupan sehari-hari. Maka dengan situasi ini, kegiatan pengabdian akan memberikan solusi berupa renovasi bangunan MCK eksisting untuk kegiatan masyarakat sekaligus sebagai sarana pendukung pariwisata desa tersebut.

Dari analisis situasi lapangan maka pada pelaksanaan pengabdian masyarakat ini permasalahan yang dapat dilapangan yaitu kurangnya fasilitas pendukung wisata antara lain adalah fasilitas sanitasi yaitu MCK yang nyaman digunakan oleh para turis. Renovasi MCK ini merupakan dukungan terhadap meningkatnya kunjungan wisatawan ke Kabupaten Karo ini. Sarana MCK merupakan sarana yang penting dalam mendukung terlaksananya wisata yang bersih dan nyaman. Untuk itu pembangunannya layak sebagai bagian dari program pemerintah dibidang pariwisata. Fasilitas ini selain untuk para turis juga dapat digunakan oleh masyarakat setempat dalam hal pemenuhan kebutuhan sehari-hari.

Permasalahan yang terdapat akan diselesaikan dengan kegiatan yang melibatkan masyarakat setempat. Kegiatan ini dipersiapkan untuk menghadapi peningkatan arus kunjungan wisatawan. Selain itu kegiatan ini juga dibutuhkan untuk memenuhi keperluan masyarakat setempat. Solusi yang ditawarkan adalah memperkuat kegiatan pelayanan terhadap waisatawan dan masyarakat melalui renovasi MCK untuk masyarakat.

Dalam renovasi MCK ini juga difasilitasi dengan tempat untuk mencuci baju bagi masyarakat. Solusi ini dikerjakan dari mulai perencanaan bangunan MCK serta pembangunan renovasi fisik dilapangan. Kegiatan ini merupakan kegiatan dengan durasi yang panjang dan biaya yang besar. Tetapi, diharapkan solusi ini dapat segera dilaksanakan.

Pada pengabdian masyarakat ini targetnya adalah wisatawan dan masyarakat pada desa tersebut. Sebuah bangunan merupakan pemenuhan kebutuhan manusia yamg masing-masing memiliki makna dan interpretasinya (Hale, 2000). Untuk itu bangunan dengan fungsi apappun dapat memberikan interpretasi sesuai dengan situasi yang ada. Jadi pembangunan MCK ini selain dapat berkontribusi terhadap masyarakat sekitar juga sebagai pemenuhan fungsi sarana pendukung wisata. Diharapkan dengan adanya bangunan MCK ini masyarakat terbantu dengan masalah sehari-hari terutama kebutuhan air bersih.

Target yang khusus dari kegiatan ini adalah masyarakat mendapatkan manfaat dari diperbaikinya sarana MCK pada desa mereka dan sekaligus fasilitas kepada wisatawan. Pelaksanaan kegiatan ini akan dilengkapi dengan survei lapangan dan penentuan MCK yang layak untuk diperbaiki bangunannya.

\section{METODE PELAKSANAAN}

Metode pelaksanaan dari pengabdian ini adalah kegiatan dilakukan di lokasi yaitu Desa Pangambatan, Kecamatan Merek, Kabupaten Karo. Setelah mendapat kata sepakat dengan pihak 
pemerintahan desa maka tahap awal dari kegiatan pengabdian ini adalah penandatanganan surat pernyataan kesediaan bekerjasama dengan ketua pelaksanaan pengabdian. Setelah mendapat persetujuan maka pelaksanaan kegiatan pengabdian dapat dilakukan setelah acara penandatanganan kontrak pengabdian antara Ketua Pelaksana Pengabdian dengan Ketua Lembaga Pengabdian Masyarakat USU selesai dilaksanakan.

Pelaksanaan pengabdian di lokasi dilakukan dengan partisipasi mitra setempat. Partisipasi awal ditunjukkan dengan adanya persetujuan untuk melaksanakan kegiatan ini oleh Kepala Desa setempat. Partisipasi selanjutnya diharapakan dukungan masyarakat pada saat proses perbaikan yang memakan waktu cukup lama dan dibutuhkan banyak tenaga pekerja bangunan.

Lokasi renovasi MCK ini merupakan lokasi yang didiskusikan dengan Kepala Desa dan masyarakat setempat agar dicapai kesepakatan dan mencegah ada masalah dibelakang hari. Selain itu proses pembangunan membutuhkan banyak tenaga setempat, untuk itu partisipasi masyarakat sangat dibutuhkan peranannya. Melalui bentuk partisipasi mitra ini diharapakan kegiatan ini dapat terlaksana dengan baik dan sesuai dengan jadwal pelaksanaan yang telah ditetapkan.

Rencana kegiatan dari pelaksanaan kegiatan ini dimulai dengan tahapan diskusi dengan Kepala Desa. Selanjutkan tim melakukan survei lapangan sekaligus bersama warga dan Kepala Desa bersepakat terhadap lokasi pembangunan MCK. Setelah dicapai kesepakatan maka proses perencanan dapat dilakukan oleh tim pelaksana pengabdian. Proses perencanaan menghasilkan gambar kerja bangunan MCK dan RAB yang dapat berfungsi sebagai panduan dalam proses pembangunannya. Dengan dana yang tersedia maka proses pembangunan mulai dilaksanakan dengan melibatkan partisipasi masyarakat sekitar. Kegiatan ini dijabarkan pada Tabel 1. dibawah ini.

\begin{tabular}{llcc}
\hline \multicolumn{1}{c}{ Tahap } & \multicolumn{1}{c}{ Kegiatan } & Bentuk & Waktu \\
\hline Survei & Survei & Diskusi & $1-2$ hari \\
Lokasi & Diskusi dengan Kepala Desa & Diskusi & $1-2$ hari \\
Renovasi Fisik & Renovasi MCK & Proses Fisik & $1-2$ bulan \\
\hline
\end{tabular}

Tabel 1. Pelaksanaan Kegiatan

\section{HASIL DAN PEMBAHASAN}

Pelaksanaan survei lokasi bersama dengan perangkat desa setempat bertujuan untuk melihat keberadaan MCK pada Desa Pagambatan ini. Desa ini memiliki 2 buah MCK yang telah lama dibangun dan kondisinya sangat perlu untuk diperbaiki. Dari hasil kunjungan diputuskan bahwa hanya satu MCK yang dapat diperbaiki karena keterbatasan dana. Mudah2an selanjutnya MCK yang lain dapat diperbaiki dengan dana yang lain pula.

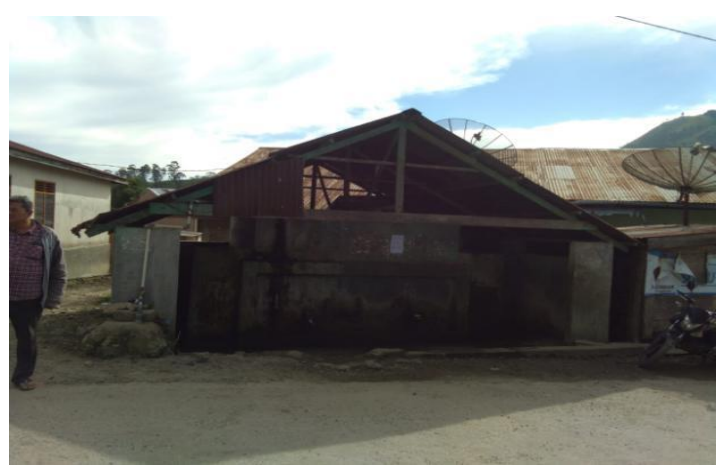

Gambar 2. Lokasi MCK 1 


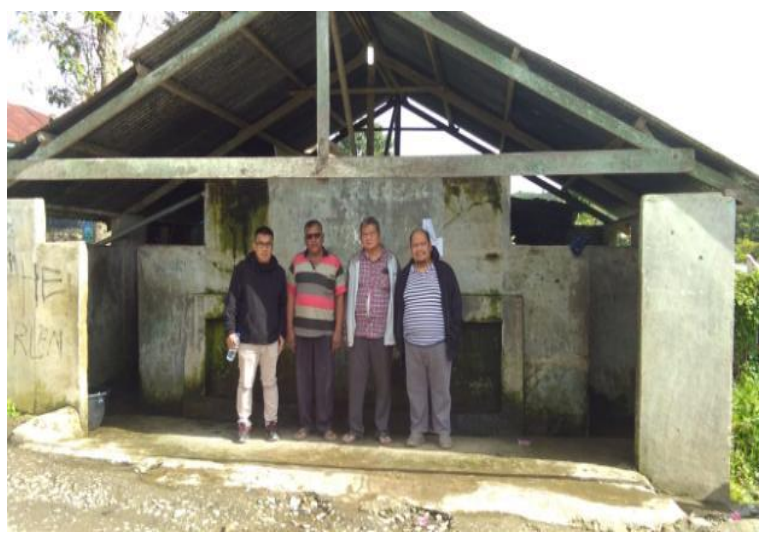

Gambar 3. Lokasi MCK 2

Penetapan lokasi dan membicarakan perihal kegiatan ini lewat acara FGD (Focus Grup Discussion) dengan pihak aparat desa setempat. Kegiatan ini dilakukan di rumah Sekrestaris Desa yaitu bapak Marsion dan dihadiri oleh beberapa warga desa yang lain.

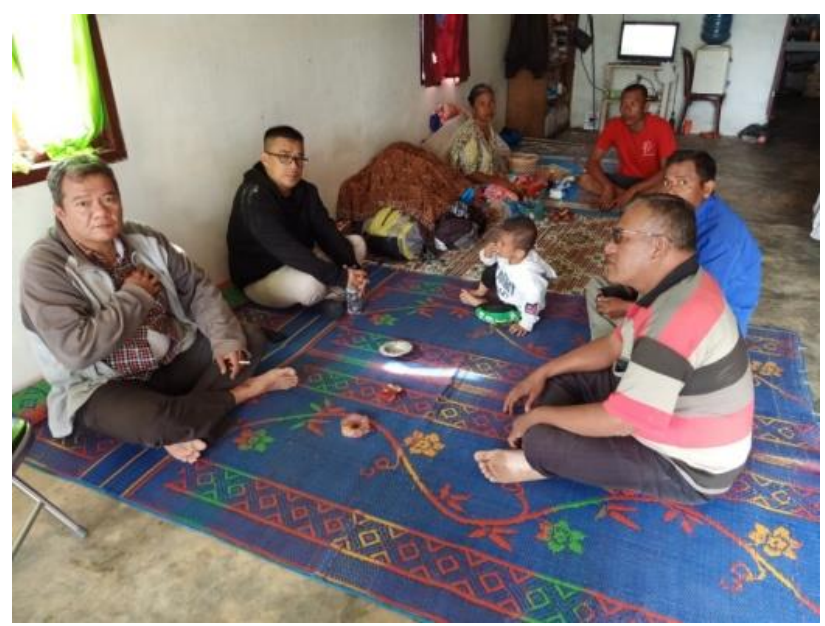

Gambar 4. Diskusi

Tahap perencanaan adalah tahap untuk mengidentifikasi kerusakan pada MCK terutama material yang ada pada bangunan itu. Setelah diidentifikasi maka diputuskan untuk merenovasi dinding, rangka kuda-kuda, closet, penutup atap dan saluran air. Dari beberapa material ini beberapa dibeli yang baru karena yang lama sudah cocok untuk diganti. Dari tahap perencanaan maka akan dilaksanakan tahap renovasi fisik bangunan MCK tersebut.

Tahap selanjutnya adalah tahap pelaksanaan yang dikerjakan oleh tukang bangunan dan diawasi langsung oleh aparat desa.

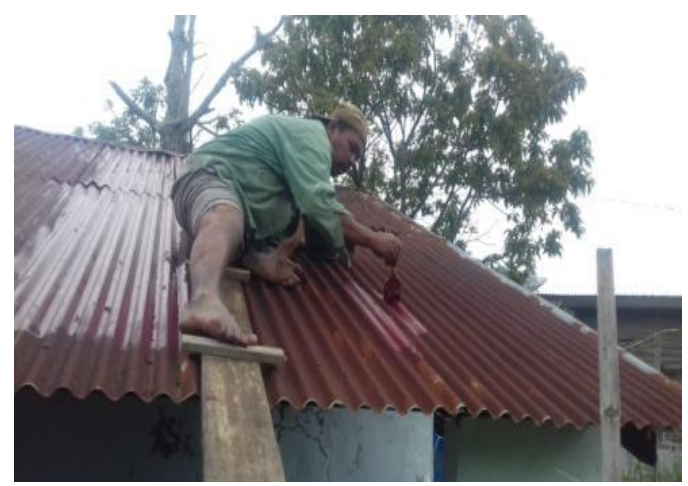




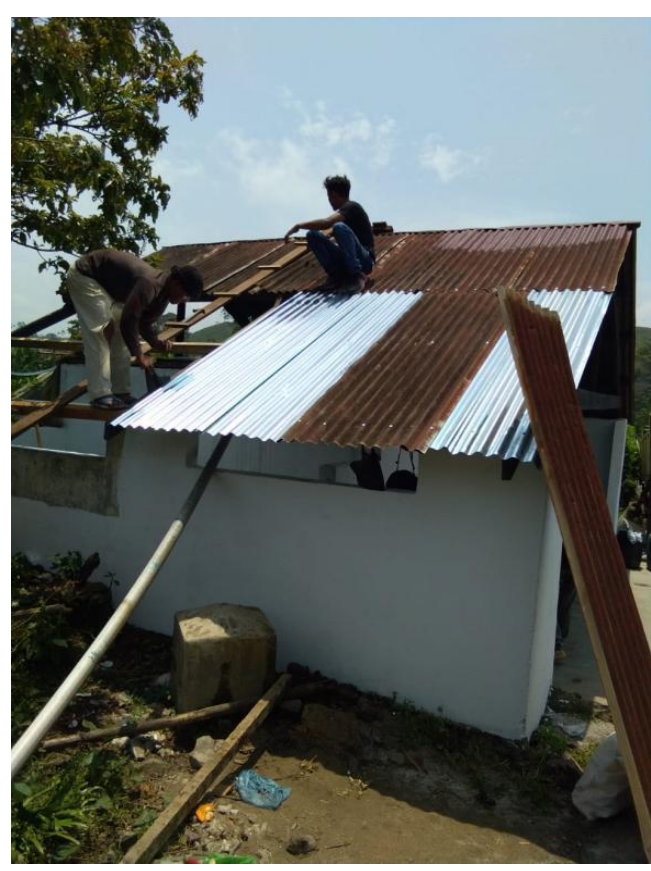

Gambar 5. Pelaksanaan Renovasi

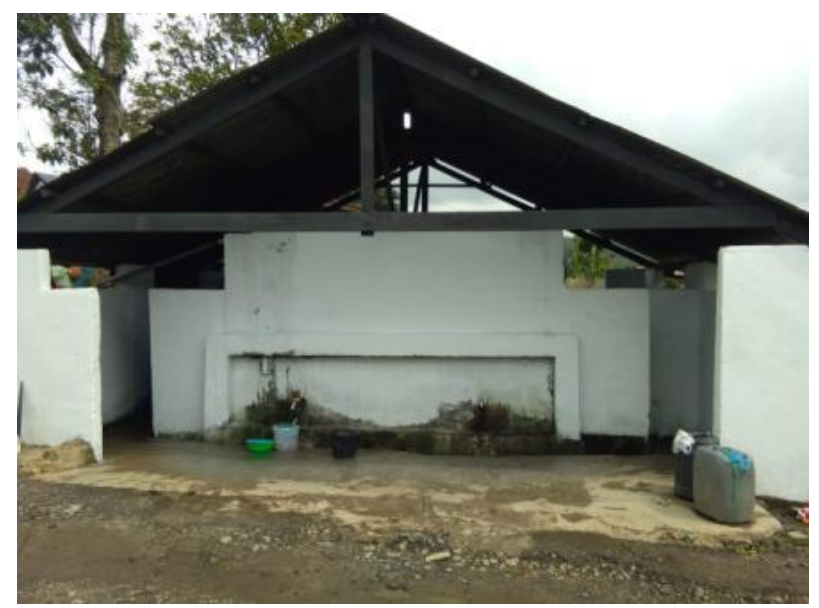

Gambar 6. Bangunan MCK selesai Renovasi

\section{KESIMPULAN}

Adapun kesimpulan yang dapat ditarik dari kegiatan pengabdian masyarakat ini adalah masyarakat sangat membutuhkan dalam hal peningkatan sarana MCK. Masyarakat menyambut baik dengan adanya renovasi bangunan MCK ini supaya selanjutnya dapat ditingkatkan lagi penggunaannya. Saran yaitu kegiatan ini diharapkan dapat terus berlanjut untuk meningkatkan fasilitas desa melalui program mono tahun pada Lembaga Pengabdian Kepada Masyarakat USU.

\section{UCAPAN TERIMAKASIH}

Penulis mengucapkan terima kasih kepada Universitas Sumatera Utara yang telah memberikan kesempatan untuk melaksanakan kegiatan Pengabdaian Mono Tahun ini melalui kontrak Nomor : 
327/UN5.2.3.2.1/PPM/2019, Tanggal 20 Mei 2019. Penulis juga mengucapkan terima kasih kepada Kepala dan Sekretaris Desa Pangambatan Kecamatan Merek Kabupaten Karo Propinsi Sumatera Utara yang telah mendukung kegiatan ini sampai selesai.

\section{DAFTAR PUSTAKA}

Ginting, Nurlisa. \& Rahman, N.Vinky. (2016). Maimoon Palace heritage District in Medan, Indonesia: What we preserve and why we preserve?, Procedia-Social Behavioral Sciences 222 , p.332-341.

Hale, Jonathan A. (2000). Building Ideas - An Introduction to Architectural Theory, John Wiley \& Sons Ltd, England.

Norberg-Schulz, Christian. (1980). Genius Loci Towards A Phenomenology of Architecture. Rizzoli, New York.

Tuan, Yi -Fu. (1977). Space and Place The Perspective of Experience. Minneapolis: University of Minnesota Press 